of the enzymes involved, however, remains an open question and will form the basis for future investigations.

Albert Delaunay

JACQUELINE LEBRUN

Institut Pasteur,

MARY Barber

Annexe à Garches.

Dec. 29.

' Comandon, J., Ann. Inst. Pasteur, 34, 1 (1920).

2 Delaunay, A., and Pages, J., Ann. Inst. Pasteur, 72, 458 (1916).

"Delaunay, A., Robineaux, R., and Lebrun, J., Rev. Immunol., 14, $262(1950)$.

${ }^{4}$ Delaunay, A., Ann. Inst. Pasteur, 70, 372 (1944).

${ }^{5}$ Lebrun, J., Pages, J., and Robineaux, R., Ann. Inst. Pasteur, 79 416 , (1950).

${ }^{6}$ Agner, Advances in Enzymology, 3, 137 (1913).

\section{Effect of Partial Acetylation on Jute}

Partial acetylation as a means of arresting the development of the yellow to brown colour, produced by photochemical reactions on irradiating bleached jute with a mercury vapour lamp, has been suggested by Peill'1, and Callow and Speakman ${ }^{2}$. The development of this undesirable shade in untreated and bleached jute has been postulated by the latter as mainly due to a sequence of reactions involving the lignin molecule, presumably through the formation of $o$-phenols and subsequent conversion to $o$-quinones. These authors are also of opinion that some discoloration may be caused by the polymerization of furfural liberated from pentosans, or result from condensation reactions between furfural and phenolic groups of lignin. On acetylation, however, the phenolic and alcoholic hydroxyl groups in juts are blocked, and consequently the possibility of the above reactions leading to discoloration is avoided.

During partial acetylation of a cellulosic fibre, the reaction is supposed to take place in a topochemical fashion, and unless the acetylated layer is removed by some suitable solvent, the reaction is expected to be confined to the surface layor of the fibre. Jute is basically composed of cellulose, hemicelluloses, and lignin, and the relative proportion of their hydroxyl groups occurring at the surface layer, which are free for acetylation, is not known. It was therefore considered of importance to determine the relative amounts of acetyl groups which reacted with individual fibre components during the acetylation of jute.

The untreated or bleached jute fabric ( $3 \mathrm{gm}$.$) , when$ subjocted to partial acetylation by refluxing the material with a mixture of acetic anhydride (30 gm.)

\begin{tabular}{|c|c|c|c|c|}
\hline Sample & $\begin{array}{c}\text { Loss in } \\
\text { wt. due to } \\
\text { chemical } \\
\text { treatment } \\
\text { (per cont) }\end{array}$ & $\begin{array}{l}\text { Tncrease } \\
\text { in wt. due } \\
\text { to acetyl- } \\
\text { ation (per } \\
\text { cent) }\end{array}$ & $\begin{array}{l}\text { Initial } \\
\text { acetyl } \\
\text { content } \\
\text { of the } \\
\text { material } \\
\text { (per } \\
\text { cent)* }\end{array}$ & $\begin{array}{l}\text { Intro- } \\
\text { duced } \\
\text { acetyl } \\
\text { content } \\
\text { (per } \\
\text { cent)* }\end{array}$ \\
\hline Purifled cotton & - & $4 \cdot 3$ & $\mathrm{Nil}$ & $4 \cdot 36$ \\
\hline Jute $a$-cellulose & $39 \cdot 7$ & $3 \cdot 3$ & $0 \cdot 79$ & $4 \cdot 60$ \\
\hline $\begin{array}{l}\text { Dewaxed untreat- } \\
\text { ed jutc }\end{array}$ & 一 & $11 \cdot 9$ & $5 \cdot 94$ & $13 \cdot 55$ \\
\hline $\begin{array}{l}\text { Jute bleached by } \\
\text { treating success- } \\
\text { ively with }\end{array}$ & & & & \\
\hline $\mathrm{NaOCl}$ and $\mathrm{H}_{2} \mathrm{O}_{2}$ & $8 \cdot 2$ & $13 \cdot 5$ & $3 \cdot 09$ & $14 \cdot 52$ \\
\hline $\begin{array}{l}\text { Jute holoceliulose } \\
\text { Dewaxed jute fab- }\end{array}$ & $16 \cdot 8$ & $11 \cdot 7$ & $4 \cdot 06$ & $14 \cdot 28$ \\
\hline $\begin{array}{l}\text { ric boiled with } \\
\text { alkali }\end{array}$ & $26 \cdot 6$ & $10 \cdot 8$ & $0 \cdot 34$ & $11 \cdot 95$ \\
\hline
\end{tabular}

* Expressed on bone-dry unacetylated material. and xylene $(30 \mathrm{gm}$.$) in the presence of sulphanilic$ acid $(0.06 \mathrm{gm}$.) as a catalyst for four hours, during which time a definite equilibrium was reached, showed that a high content of acetyl had been intro. duced. Under the same conditions, however, only a smaller fraction of the available acetyl reacted either with cotton or $\alpha$-cellulose isolated from jute. This greater affinity of jute for acetyl groups is therefore most likely due to the presence of hemicelluloses or lignin or both. Since holocellulose isolated by two successive treatments with sodium chlorite solution $\left(0.7\right.$ per cent) at $p \mathrm{H} 4$, at $100^{\circ} \mathrm{C}$., takes up a greater arnount of acetyl (see table) than when the hemicelluloses are eliminated from jute fabric by boiling with 10 per cent caustic soda solution, which also removes only a small quantity of lignin, it seems likely that when untreated or bleached jute is acetylated, the hemicelluloses are responsible for more of the acetyl groups attacked compared with lignin. Furthermore, as the isolated jute $\alpha$-collulose is capable of reacting with only a small amount of acetyl, it is probable that, during acetylation of untreated or bleached jute, the cellulosic component plays a less important part compared with hemicelluloses and lignin.

\section{W. G. MACMILIAaN}

A. B. Sen Gupta

Research Institute,

Indian Jute Mills Association,

Calcutta 27.

Dec. 29.

${ }^{1}$ Peill, Nature, 158, 554 (1946).

${ }^{2}$ Callow and Speakman, J. Soc. Dyers and Col.. 65, 758 (1949).

\section{'Lampbrush' Fibres in the Chromosomes of Chrotogonus incertus Bolivar}

ThE meiotic chromosomes of the grasshopper, Chrotogonus incertus Bolivar (collected at Allahabad), assume typical 'lampliush' appearance at pachytene, which condition persists to the end of diakinesis, but disappears completely at the first metaphase. This condition has been reported by $\mathrm{Hsu}^{2}$ in two different species of grasshoppers, and, judging from illustrations, it seems to have been observed in grasshoppers by other investigators also, even though they do not explicitly describe $\mathrm{it}^{2,3}$. Hsu ${ }^{1}$ has put forward an ingenious theory, based essentially on Goldschmidt's ${ }^{4}$ interpretation of the 'lampbrush' chromosome, which links up spiralization, heteropycnosis and the formation of 'lampbrush' processes. According to him, heterochromatinic heteropyenosis is not due, at least not entirely, to differential nucleic acid synthesis ${ }^{5}$, but to a difference in the capacity to undergo cyclic condensation. Negative heteropycnosis results from the fact that the intracellular conditions permit the growth of 'lampbrush' fibres on the $X$-chromosome, whereas the autosomes become compactly coiled. Positive heteropycnosis results when the conditions are reversed; the $X$-chromosome undergoes condensation, but not the autosomes, which, in consequence, show the 'Iampbrush' fibres. Polymerization of the nucleoprotein, he claims, causes the chromosomes either to be coiled or show 'lampbrush' fibres. Now in the spermatocytes of Chrotogonus, late diakinetic chromosomes, although considerably condensed and consequently much shorter than the pachytene threads, are provided with 'lampbrush' fibres similar in size and shape to those of the earlier stages. So, condensation (spiraliza- 